\title{
Examination and Restoration of an artifact of cartonnage from komombo excavation, Egypt
}

- Prof. Amany Mohamed Kamel Abu Krorra - Professor of Archaeology Restoration - Faculty of Archaeology, Fayoum University - Former Dean of the Faculty of Archaeology, Aswan University

- Prof. Abdu Abd Allah Omran El -Derby - Professor and Head of the Restoration Department Faculty of Archaeology - South Valley University.

- Hassan Taky Hussein Ismail - Conservation Specialist - Ministry of Tourism and Antiquities Aswan and Nubia Antiquities area

\section{Abstract}

This research aims to identify the components of an archaeological artifact of Cartonnage dating back to the Roman era from an excavation in southern Egypt, Komombo area, by examining and analyzing chromatic (colorful) samples from it.

And for this purpose the light optical microscope (LOM) and scanning electron microscope coupled with energy dispersive X-ray analysis (SEM-EDX) are used. And the Fourier transforms infrared spectroscopies (FTIR) is used to identify the quality of the preparation layer and the bonding material (animal glue) and it was found that the preparation layer is Consists of calcite (a compound Calcium carbonate).

Examining samples of the preparatory layer of the artifact, it became clear that it consists of two layers, the first coarse layer is composed of Calcium carbonate and the second layer is fine and smooth and the layers were identified and thicknesses were calculated by SEM-EDX.

The treatment plan for the artifact included consolidation it after cleaning it with klucel G dissolved in ethyl alcohol with $3 \%$ concentration for the colored parts of the cartonnage, also included injection of cracks and micro-cracks and consolidation the weak parts using paraloid B72 dissolved in acetone with $3 \%$ concentration.

\section{Key words}

Cartonnage - pigments - X-ray diffraction - SEM-EDX - FTIR - Consolidation.

\section{Introduction}

The ancient Egyptians were concerned with preserving the body of the deceased in the best possible condition for as long as possible, as they believed in the concept of resurrection and immortality after death, and this was related to preserving his mummy and image. So that his soul (alba as well as alka) could recognise him and return to his mummy (Putnam, 2009). And since the middle kingdom, masks were made for the deceased's head and through it an ideal image of the deceased was represented (Walker, 1997).
The mask depicting the deceased's head was made up of layers of linen that were glued together, then covered with a sheet of gypsum, and finally coloured and gilded on top of that layer (Gansicke, 2010, Taylor,1989). The body of the deceased was wrapped in linen wraps to keep it safe (Sliver Man, 1997), and it was painted after a layer of gypsum was placed as a preparation layer, followed by painting, colouring, and gilding on the top of that layer. 


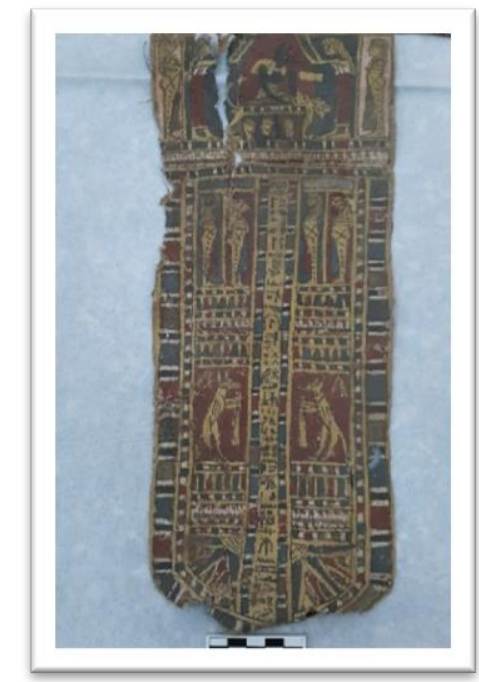

fig.(1) shows the shape of the apron and dates back to the Roman era

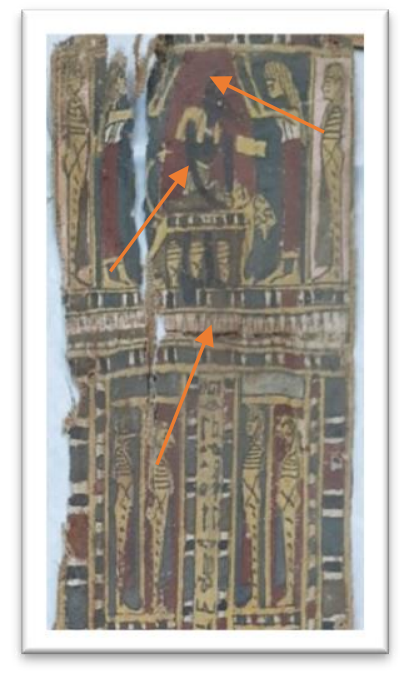

fig.(2) shows the signs of damage on the apron in the upper part of the presence of dust, dirt, and tearing of the linen tissue, and the presence of peeling in colors.
Cartonnage decoration began in the Middle Kingdom with feathers and drawing eyes and drawing moustaches and beards for men, and women's chest was embodied, and women's masks coupled with a waistcoat and a wide neaklace around the deceased's neck (Dodson A, Ikram, S, 1998).

In the modern state, a linen covered with a layer of glided gypsum was used. And in the Roman Times, masks were still used, and eyes were grafted to increase their proximity to reality. And in the Ptolemaic period, the cartonnage support appeared to be made from several layers of pressed papyrus instead of layers of glued linen. ) (1997، فر انسو ا دونان\& روجيه ليشينرج (.)

Then it became composed of several pieces, not one piece, as in other eras, it was one part covered the entire body, but it became four or five parts (Mask - Pectoral - Stomach - Apron - Boot).

A piece of cartonnage which is possible dating back to the roman era has been studied, and it is preserved in the museum store in Komombo, and it was discovered and uncovered in the Elshatb excavation in
Komombo in about 1904. This piece was a cartonnage apron dating back to the Roman era, which was registeres with the number (1480). It measures 39 centimeters in length and 15 centimeters in width

(Fig. 1\&2).

\section{By examining it was found that the stratigraphic structure of cartonnage objects in general consists of the following:}

\section{Support}

At this time, linen rolls were used, which were glued together with an animal glue, then covered with a layer of gesso, followed by a colorful layer (Walker S,

Bier brier M, 2000).

\section{Preparation layer}

The used preparation layers used in making cartonnage varied and consisted of gypsum or lime and its purpose after preparing the holder for drawing and coloring on it, usually it was composed of a rough inner layer and an outer layer which is the soft layer.

And the preparation layer was composed of calcite (calcium carbonate) and then it is colored and gilded and the decorated it with geometric, religious and botanical shapes (David A. \& other, 2003).

\section{Painting layer}

The ancient Egyptian used natural colors; most of them are oxides that were extracted from their natural materials, so color is an important element of the art work. The ancient Egyptian used brown color to express a man's skin and used the yellow color to express a woman's complexion, and when using colors, one of the color media is added with it and from The 
colors commonly used with cartonnage, such as arsenic sulfide, were used as a source for yellow and hematite as a source for red and charcoal black as a source for black and Egyptian blue as a source for blue and calcite as a source for white and was used with a waistcoat dating back to the late era (David, A,

LynnswartzDodd, 2004), and the Egyptian blue was used The animal glue medium on cartonnage dates back to the Greco-Roman period (David, S., Megan \& Dennis, 2003), and Egyptian blue was also used with calcite in cartonnage samples dating back to the late era in Saqqara (Amani Mohamad Kamel, 2013).

\section{Materials and Methods}

Examinations and analysis were carried out on a cartonnage apron in order to diagnose the forms of damage and deterioration of the components of the studied artifact piece from the linen support, the preparation layer and the painting layer, by using the light digital microscopy, and a scanning electron microscope equipped with an EDX unit.(SEM-EDX) X-ray diffraction (XRD) was used to identify the components of the preparation layer and the layer Colorimetric infrared spectroscopy (FTIR) was used to identify the used color medium .

\section{1-1 Samples}

Samples were taken from the fallen and separated parts of the cartonnage in order to identify the signs of damage and deterioration of the apron under study and to identify the components of the preparation layer and the painting layer.

\section{2-2 Digital light microscope}

The digital light microscope was used to identify the surface of the color samples in an enlarged and clear image, and to identify the support layer, the preparatory layer and the painting layer using a digital light microscope (1000X).

\section{2-3 Scanning Electron Microscope (SEM)}

The scanning electron microscope was used to examine the components of the surface of the various samples and the preparation layer of the cartonnage samples to clarify the extent of the change that occurs in the internal composition of the surface of the samples as a result of their exposure to various damage factors. And Scanning electronic microscope was used to examine the samples under study at the laboratories of South Valley university in Qena, of the type JEOL - JSM 5500LVscanning electron microscope (JEOL JAPAN).

\section{2-4 X-ray diffraction (XRD)}

This method was used to identify the composition of materials in the form of compounds and not elements, and it is considered one of the non-destructive methods for archaeological materials. This method was used on the cartonnage pieces under study (preparation layer - painting layers). These analyzes were performed in the central laboratory in Qena using a device (EMMA 0143, GBC).

\section{2-5 Analysis using an EDX electron microscope (SEM-EDX)}

The scanning electron microscope with an EDX unit is used in the qualitative and quantitative analysis of inorganic materials that made up the archaeological materials in order to identify the elements in the cartonnage samples under study (preparation layer - painting layers) by using: SEM model Quanta 250 FEG, 
Attached with EDX Unit (Energy

Dispersive X-ray analysis), with accelerating voltage $30 \mathrm{~K} . \mathrm{V}$, Magnification $14 \mathrm{x}$ up to 1000000 and resolution for Gun.1n, FEL company, Netherlands.

\section{2-6 Fourier transforms infrared spectroscopy (FTIR)}

This analysis is used to identify the organic and inorganic materials and through the degree of absorption in the infrared range, and the sample can be identified through the functional bonds of each compound, and the range of the device was between 400 and $4000 \mathrm{~cm}^{2}$, and these analyzes were performed in the FTIR unit in the central laboratory in Qena with a (Jasco 4100 device), And this analysis was used to identify the color medium of the cartonnage components.

\section{Treatment and Restoration processing}

The treatment of an apron of cartonnage included many steps in removing the dirt, using different cleaning methods, and consolidation of the weak parts of the color layer was done using Japanese tissue paper, and it was Adhesived with klucel G $3 \%$ concentration, and then the separate parts were Adhesive by using parilod B 72 with $3 \%$ concentration dissolved in acetone.

\section{Results and discussion}

\subsection{Examination and analysis}

\subsection{Digital light microscope}

Examining the samples of the cartonnage support, it was found that it was linen and also examining the preparation layer, fig. (3) and through the examination it showed the presence of iron and silica minerals as impurities in the sample and the carrier flax, fig. (4) the examination of the blue color sample showed deep cracks appear, fig. (5).the examination of the red color sample showed impurities of silica and calcium carbonate appear in it, fig. (6). the examination of the yellow color sample showed deep cracks and fissures, fig. (7). the examination of the white color sample showed there are large and deep cracks resulting from severe dryness in the linen support, fig. (8).the examination of the black color sample showed minute and deep cracks in it, with weak cohesion with the preparation ground, which led to its separation, fig. (9).

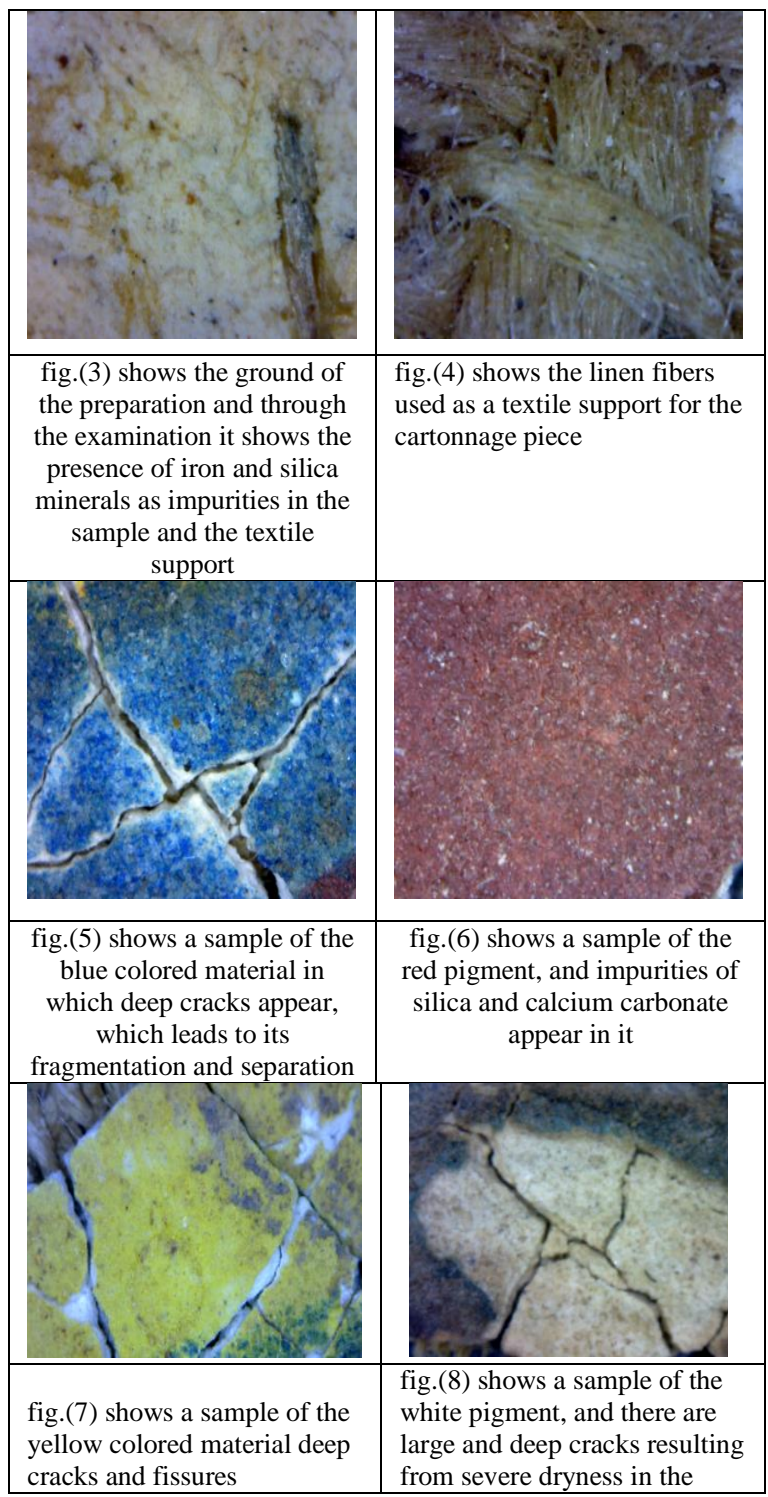




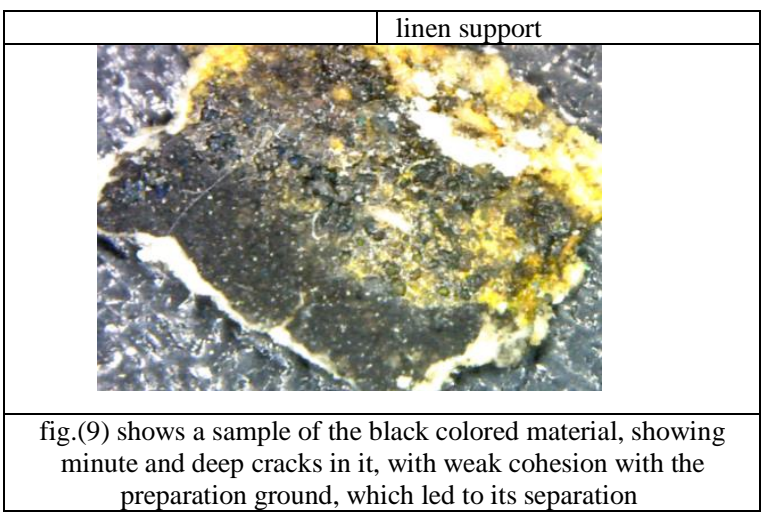

\section{3-3 Examination by a scanning electron microscope (SEM)}

Through the scanning electron microscope, it was found that the textile carrier samples were from linen and showed the extent of severe weakness between the fibers as a result of the drying of the linen carrier and its exposure to high temperatures, which led to the loss of its various mechanical properties, as well as the presence of minute cracks, which led to its fragmentation and separation and the presence of disintegration in Colorant granules due to loss of bonding material. Figs. (10) (11) (12).

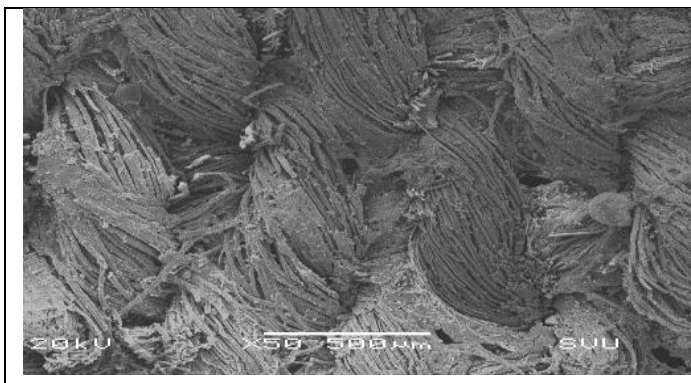

fig. (10) shows the shape of the warp and the weft of the linen fibers and the extent of severe weakness between the fibers as a result of the drying of the linen carrier and its influence with high temperatures, which led to the loss of its various mechanical properties (scanning electron microscope with a magnification power of X50)

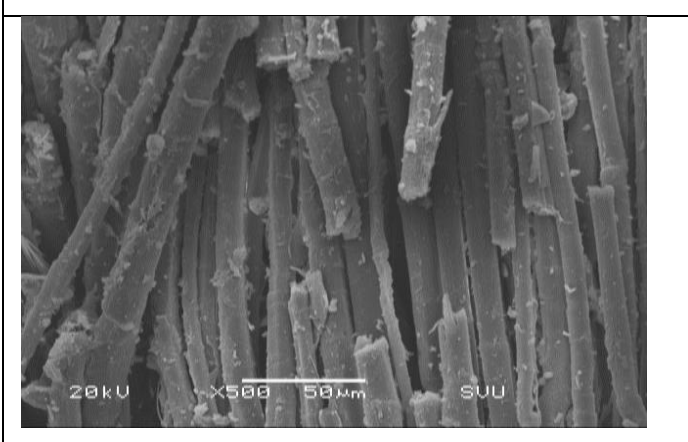

fig.(11) A sample of the linen support shows the longitudinal shape of the linen fibers and the presence of split of these fibers as a result of their weakness (scanning electron microscope with a magnification of $\mathrm{X}$ 500)

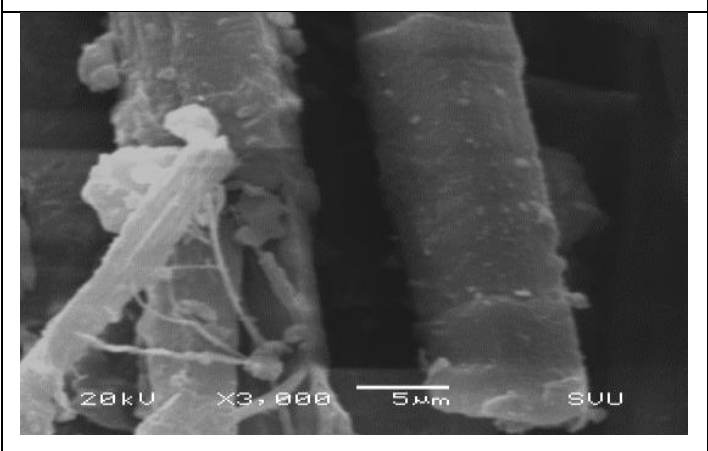

fig. (12) shows a sample from the linen support in which the remnants of fungal damage appear between the fibers and the loss of the morphological shape of the sample (scanning electron microscope with a magnification of X3000)

\section{3-4 X-ray diffraction(XRD)}

By analyzing samples from the cartonnage, we found that the sample of the preparation layer is from calcium carbonate $\mathrm{CaCO}_{3}$, Fig (13) the sample is from the red colorant from the red ferric oxide compound (hematite) $\mathrm{Fe}_{2} \mathrm{O}_{3}$, Fig (14) the sample is from the blue colorant from the calcium silicate compound and copper (Egyptian blue $\mathrm{CaCuSi}_{4} \mathrm{O}_{10}$, Fig (15) and the sample The sample is from the yellow colorant from the arsenic sulfide compound $\mathrm{AS}_{2} \mathrm{~S}_{3}$, Fig (16) the sample is from the white 
colorant from the calcite $\mathrm{CaCO}_{3}$ compound, Fig (17)and the sample is from the black pigment from the carbon black compound C, Fig (18) .

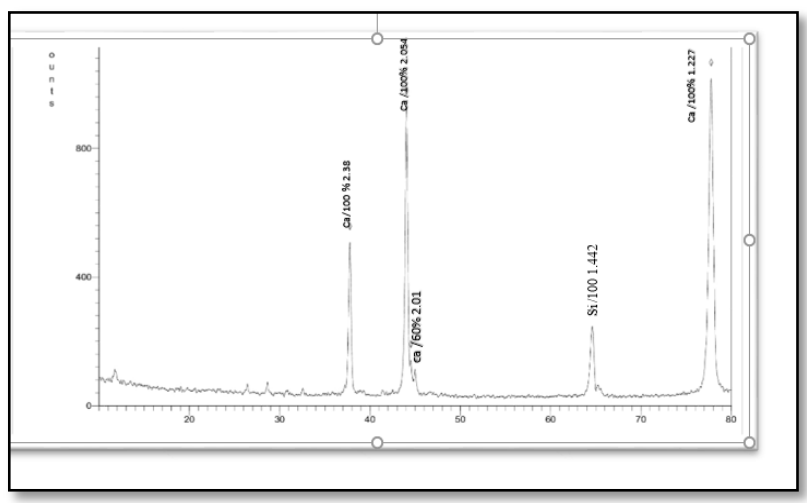

Fig. (13) Shows the pattern of X-ray diffraction (XRD) analysis of a sample of the preparatory layer

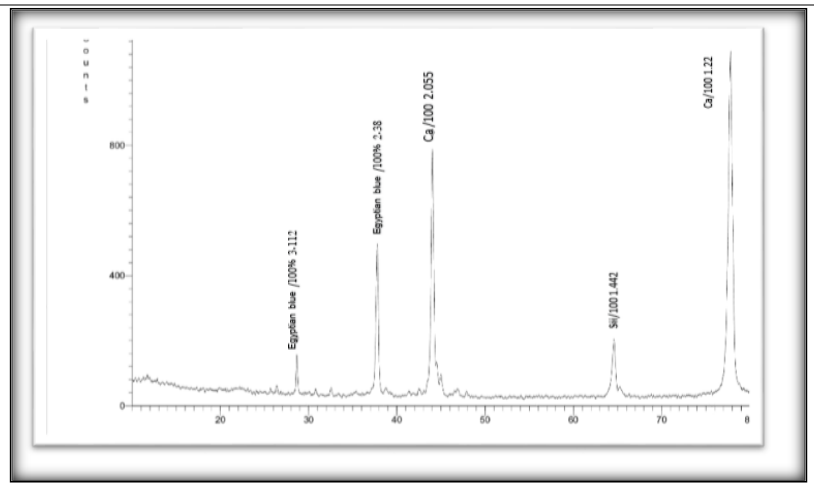

Fig. (15) shows the pattern of X-ray diffraction (XRD) analysis of a sample of blue color

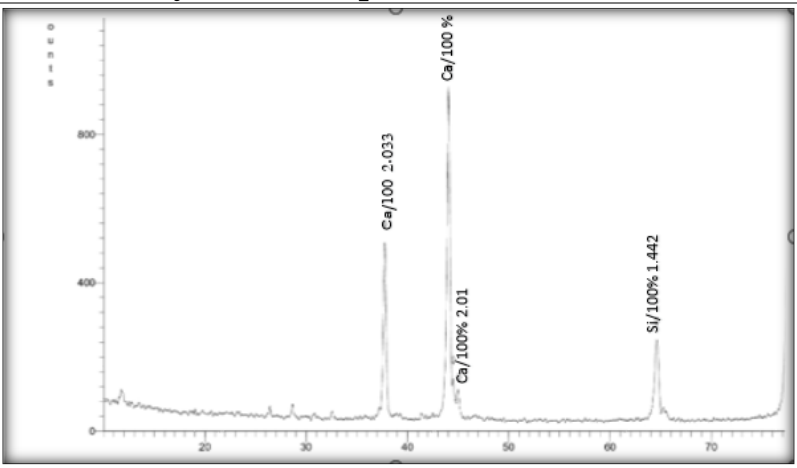

Fig (17) shows the pattern of X-ray diffraction (XRD) analysis of a sample of white color

\section{3-5 Analysis using an EDX electron microscope}

By analyzing samples from the cartonnage, we found that the elements in the sample of the preparation layer consist of calcium, quartz and carbon elements (Ca, Si, C,),fig(19) and

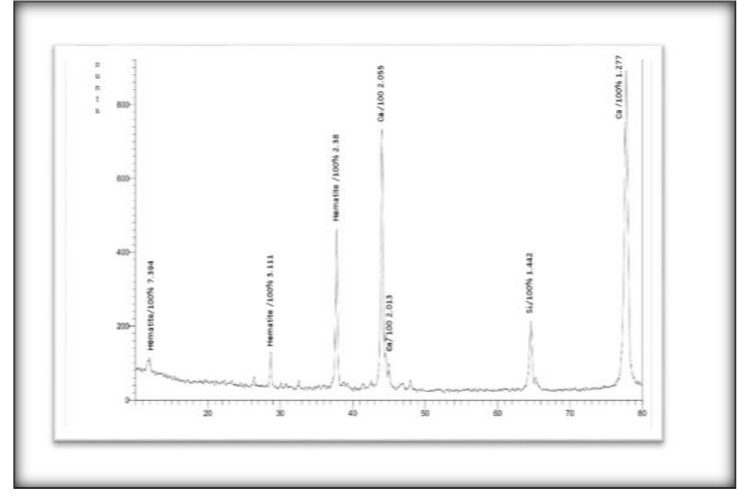

Fig. (14) Shows the pattern of X-ray diffraction (XRD) analysis of a sample of red color

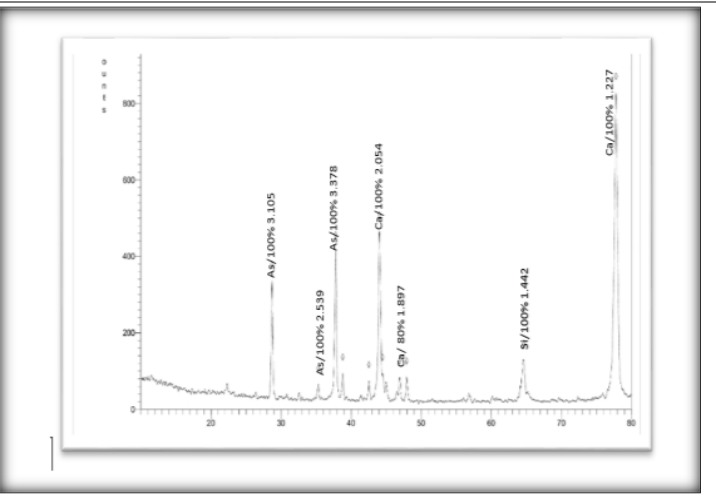

Fig. (16) shows the pattern of X-ray diffraction (XRD) analysis of a sample of yellow color

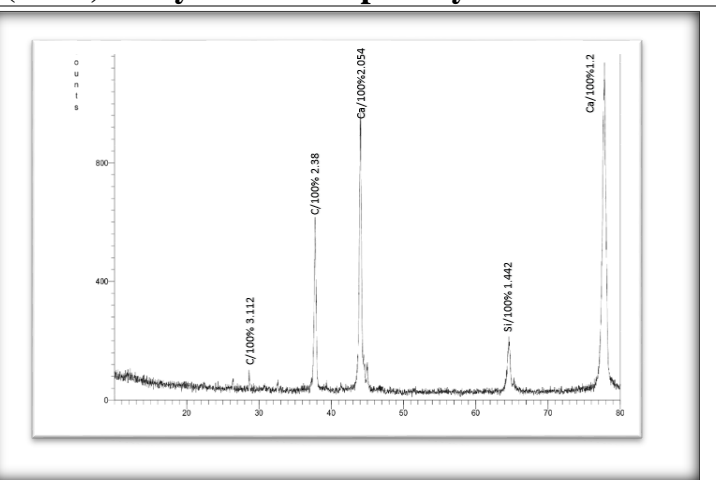

Fig (18) shows the pattern of X-ray diffraction(XRD) analysis of a sample of black color

the sample of the red colored material consists of iron, calcium, quartz and carbon elements (Ca, Fe, C, Si). ), fig(20) And the sample of the blue colorant consists of copper, silica, 
calcium and carbon elements $(\mathrm{Ca}, \mathrm{C}, \mathrm{Cu}, \mathrm{Si}$, $\mathrm{Na})$, fig(21) and the sample of the yellow colorant consists of the elements of sulfur, arsenic, calcium, carbon and quartz $(\mathrm{Ca}, \mathrm{As}$, $\mathrm{Si}, \mathrm{S}, \mathrm{C})$ fig(22) The sample of the black pigment consists of the elements of carbon, iron, calcium and quartz $(\mathrm{C}, \mathrm{Fe}, \mathrm{Si}, \mathrm{Ca}, \mathrm{Cl})$, fig(23) and the sample of the white pigment consists of elements of calcium, quartz and carbon (Ca, Si, C), fig(24).

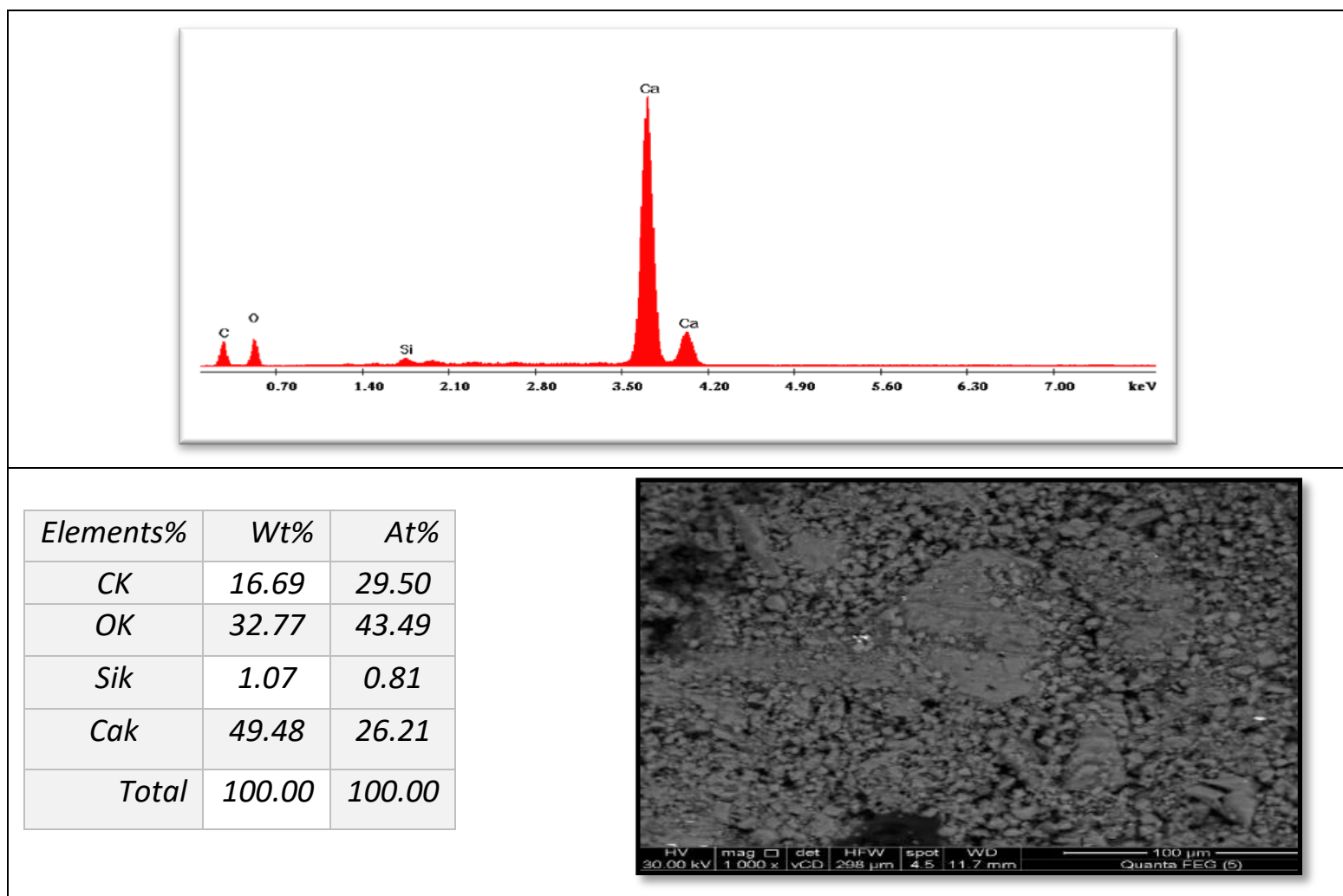

Fig 19. EDX analysis for the preparatory layer

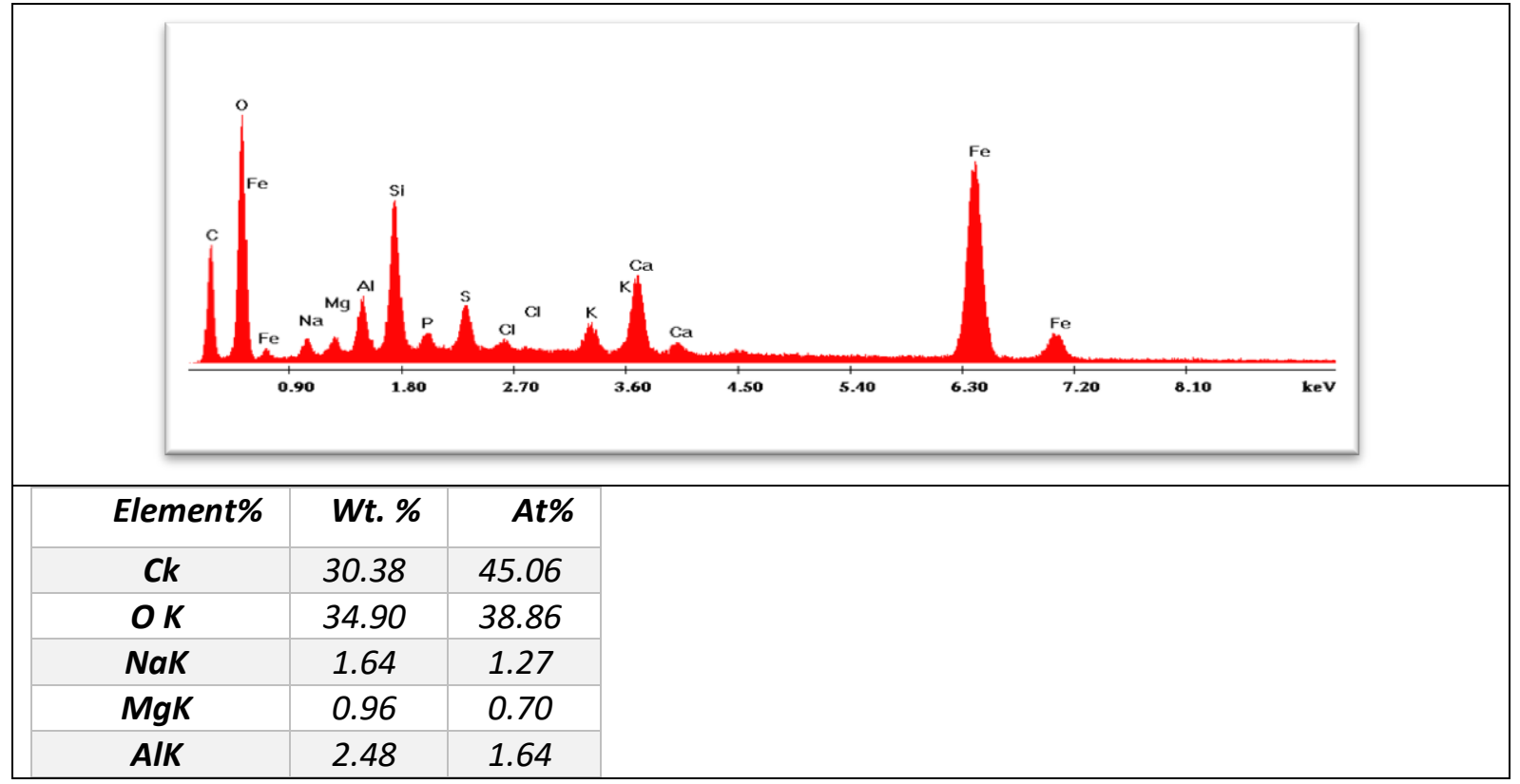


INTERNATIONAL JOURNAL OF ADVANCED STUDIES IN WORLD ARCHAEOLOGY

\begin{tabular}{|c|c|c|}
\hline SiK & 5.99 & 3.80 \\
\hline $\boldsymbol{P K}$ & 0.60 & 0.35 \\
\hline $\boldsymbol{S} \boldsymbol{K}$ & 1.65 & 0.92 \\
\hline CIK & 0.37 & 0.19 \\
\hline $\boldsymbol{K} \boldsymbol{K}$ & 1.09 & 0.50 \\
\hline CaK & 2.94 & 1.31 \\
\hline FeK & 16.98 & 5.42 \\
\hline Total & 100.00 & 100.00 \\
\hline
\end{tabular}

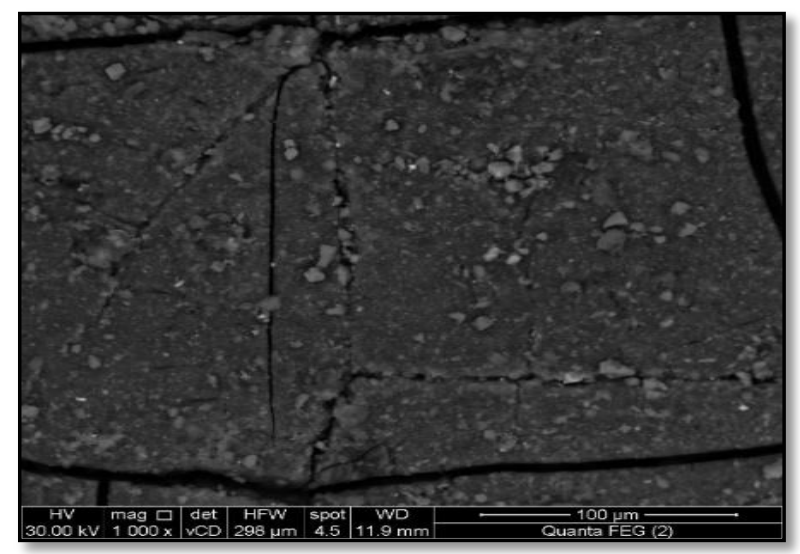

Fig 20. EDX analysis for the red pigment

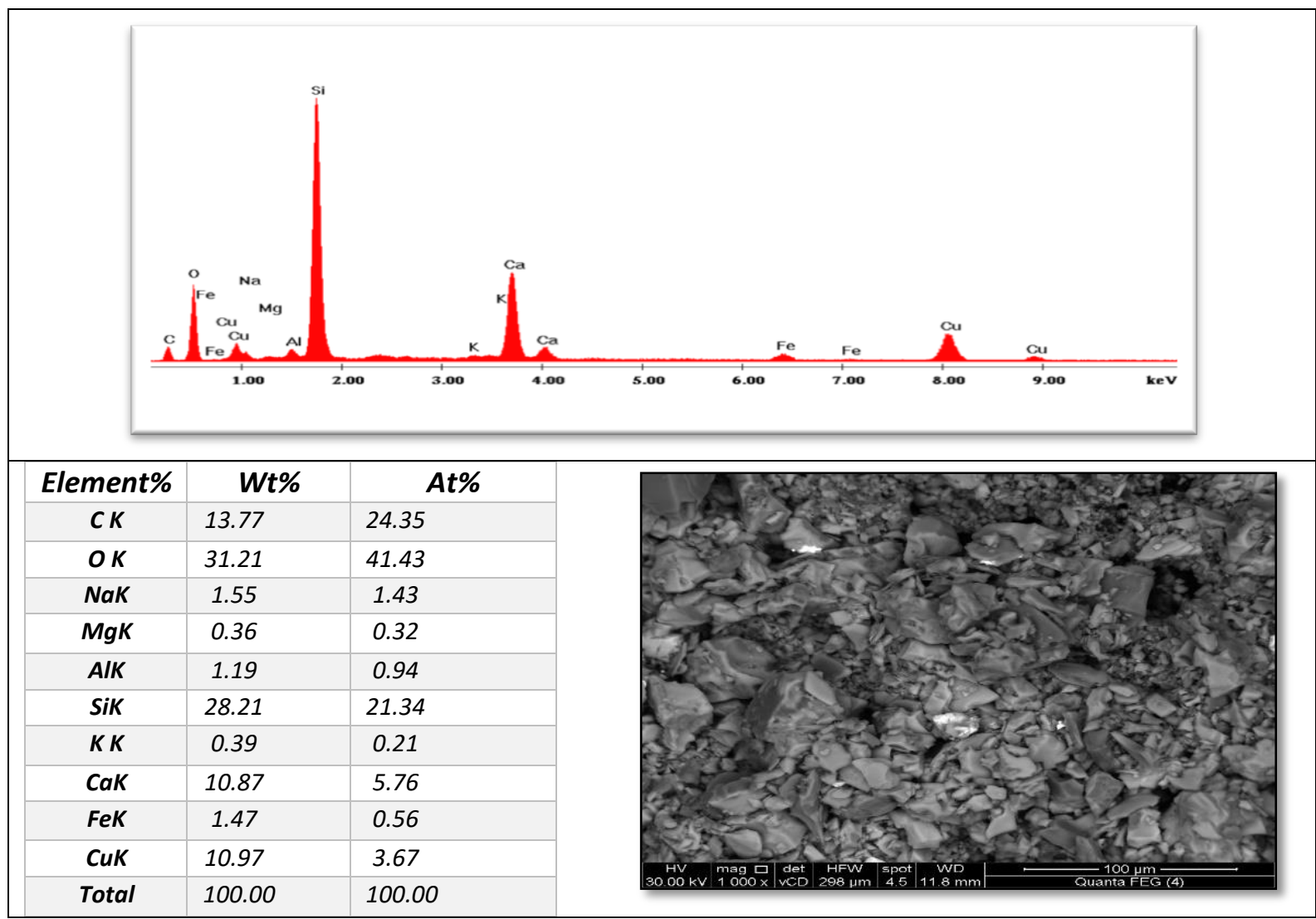

Fig 21. EDX analysis for the blue pigment 


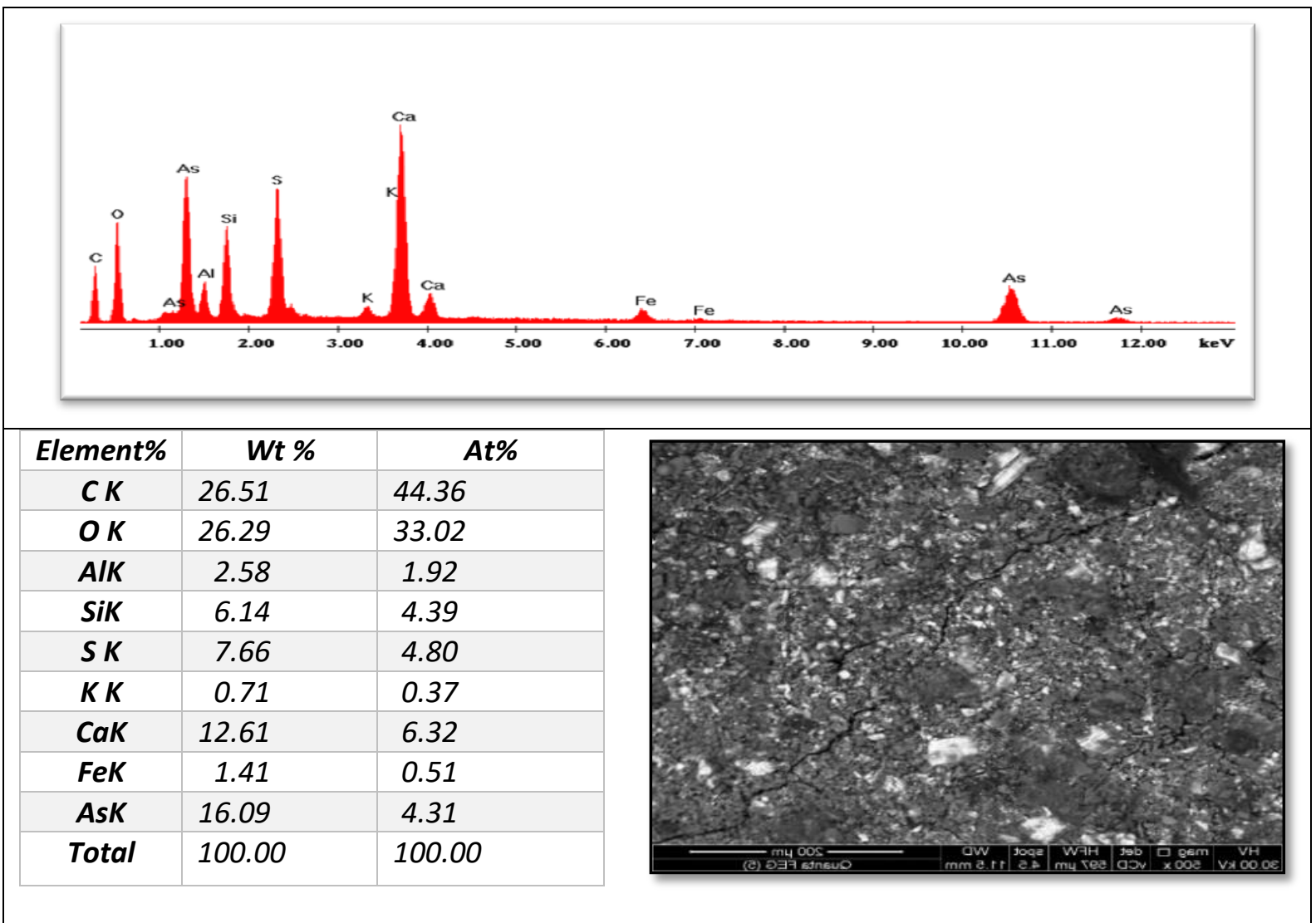

Fig 22. EDX analysis for the yellow pigment

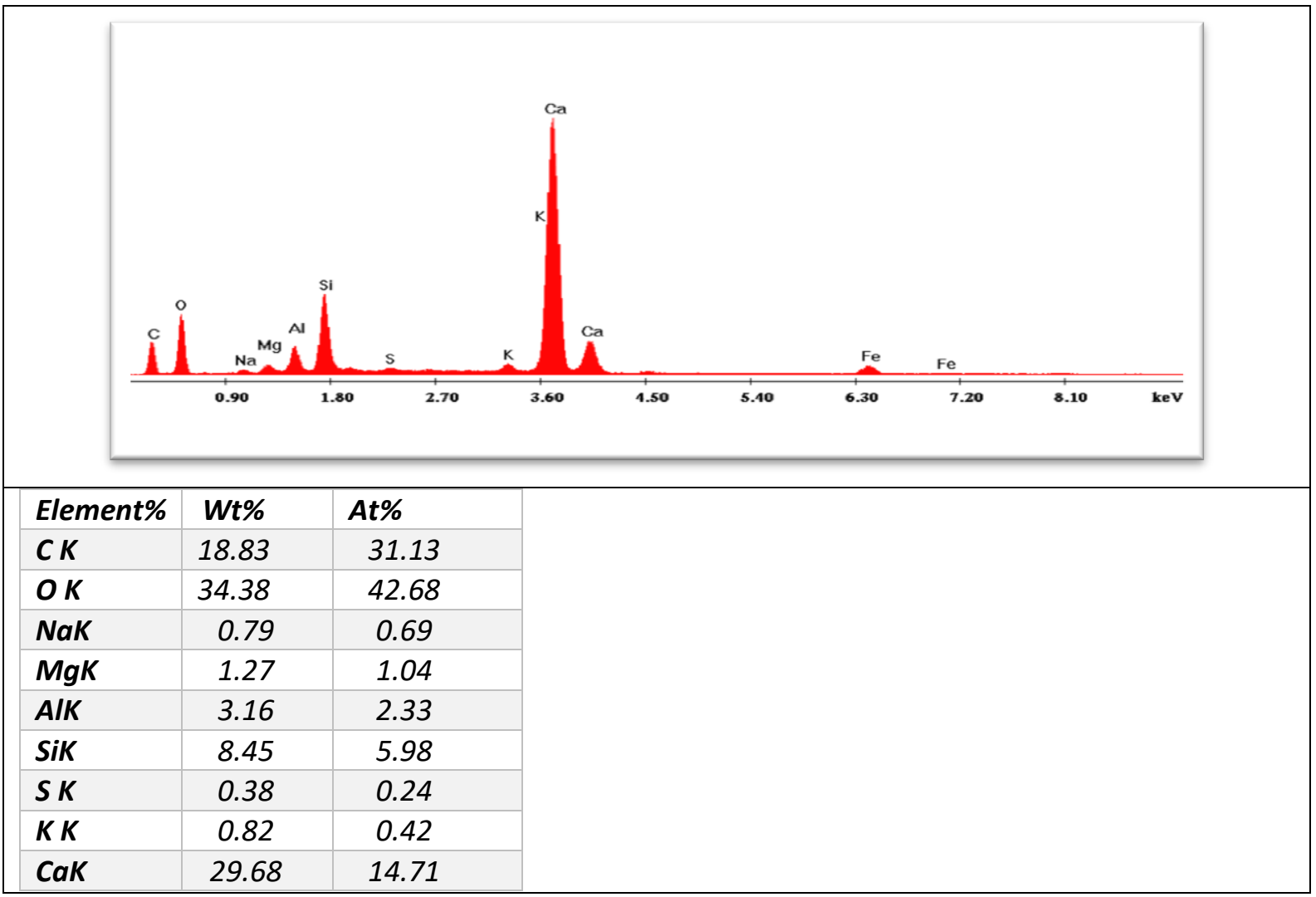


INTERNATIONAL JOURNAL OF

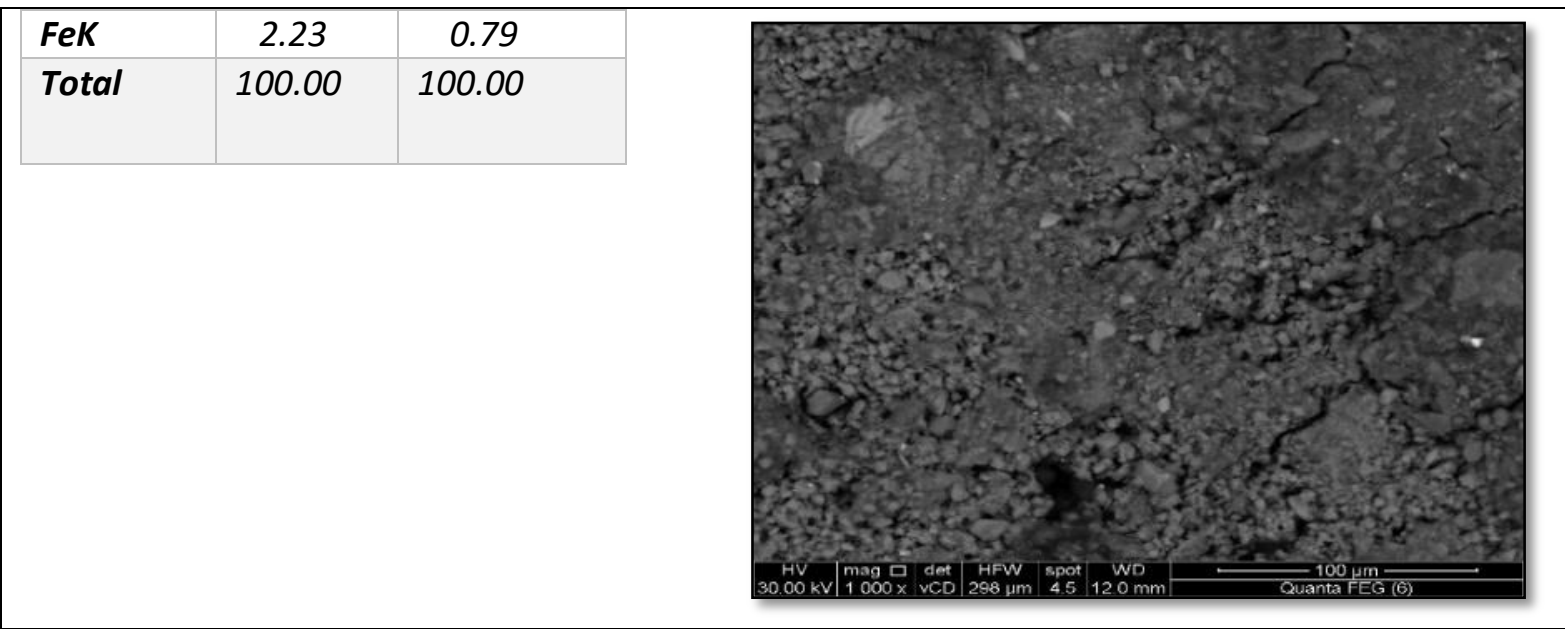

Fig 23. EDX analysis for the white pigment

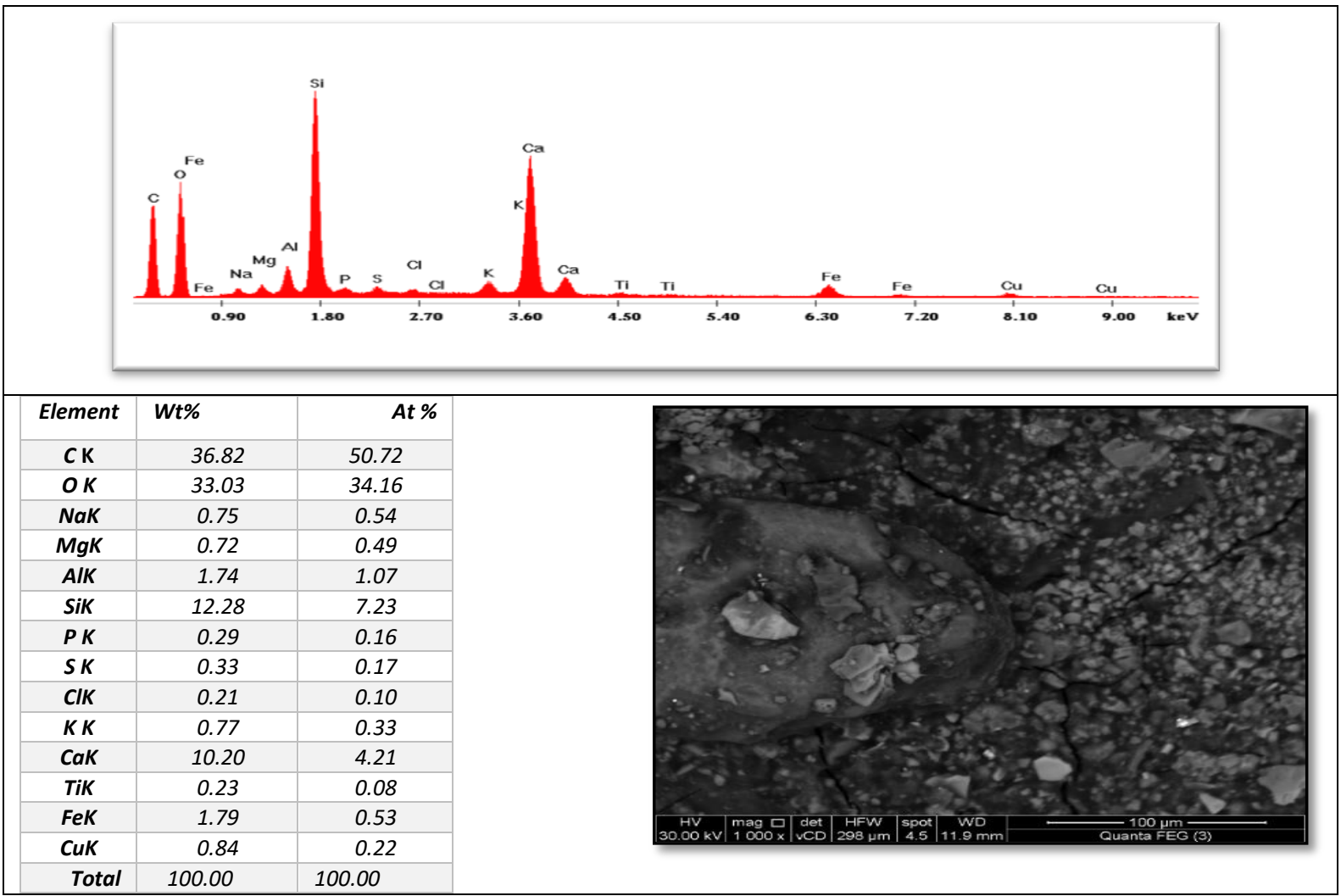

Fig 24. EDX analysis for the black pigment

\section{3-6 Fourier transforms infrared spectroscopy (FTIR)}

FTIR According to (Derrick, M.R, 1999), animal glue appears in the following functional groups:

\section{\begin{tabular}{|l|l|}
\hline Wave number & Functional group \\
\hline
\end{tabular}}

\begin{tabular}{|l|r|}
\hline $3200-3400 \mathrm{~cm}-1$ & N-H Stretching Band \\
\hline $3100-2800 \mathrm{~cm}-1$ & C-H Stretching Bands \\
\hline $1600-1660 \mathrm{~cm}-1$ & C=O Stretching Band \\
\hline $1500-1565 \mathrm{~cm}-1$ & C-N-H Bending Band \\
\hline
\end{tabular}




\begin{tabular}{|l|l|}
\hline $1300-1480 \mathrm{~cm}-1$ & C-H Bending Band \\
\hline
\end{tabular}

By comparing these functional groups that appeared for the samples the color layer proved that there is a great similarity between the standard sample and the sample under study, which confirmed that the color medium used for both the preparation ground and the color layer is animal glue.

- The first sample appeared from the red color, so the N_H group appeared at 3422.06, the C$H$ group appeared at 2873.42, the C-O group appeared at 1650.17, the $\mathrm{C}-\mathrm{N}-\mathrm{H}$ group appeared at 1560.42, and the $\mathrm{C}-\mathrm{H}$ group appeared at 1420.32 .

- The second sample appeared from the yellow color, so the N_H group appeared at 3412.42, the $\mathrm{C}-\mathrm{H}$ group appeared at 2873.42, the $\mathrm{C}-\mathrm{O}$ - The fifth sample appeared from the black color, so the $N_{-} H$ group appeared at 3428.81, the C-O group appeared at 2874.38, the $\mathrm{C}-\mathrm{H}$ group appeared at 1650.24 , the $\mathrm{C}-\mathrm{N}-\mathrm{H}$ group appeared at 1560.23, and the C-H group appeared at 1419.35. fig (25). group appeared at 1650.17, the $\mathrm{C}-\mathrm{N}$-H group appeared at 1560.42 , and the $\mathrm{C}-\mathrm{H}$ group appeared at 1420.32 .

- The third sample appeared from the blue color, so the $N$ H group appeared at 3422.06, the $\mathrm{C}-\mathrm{H}$ group appeared at 2864.74 , the $\mathrm{C}-\mathrm{O}$ group appeared at 1637.27, the $\mathrm{C}-\mathrm{N}-\mathrm{H}$ group appeared at 1560.23, and the $\mathrm{C}-\mathrm{H}$ group appeared at 1422.24.

- The fourth sample appeared from the white color, so the N_H group appeared at 3412.42, the $\mathrm{C}-\mathrm{H}$ group appeared at 2874.38 , the $\mathrm{C}-\mathrm{O}$ group appeared at 1650.24, the $\mathrm{C}-\mathrm{N}-\mathrm{H}$ group appeared at 1560.23, and the C-H group appeared at 1422.24. 


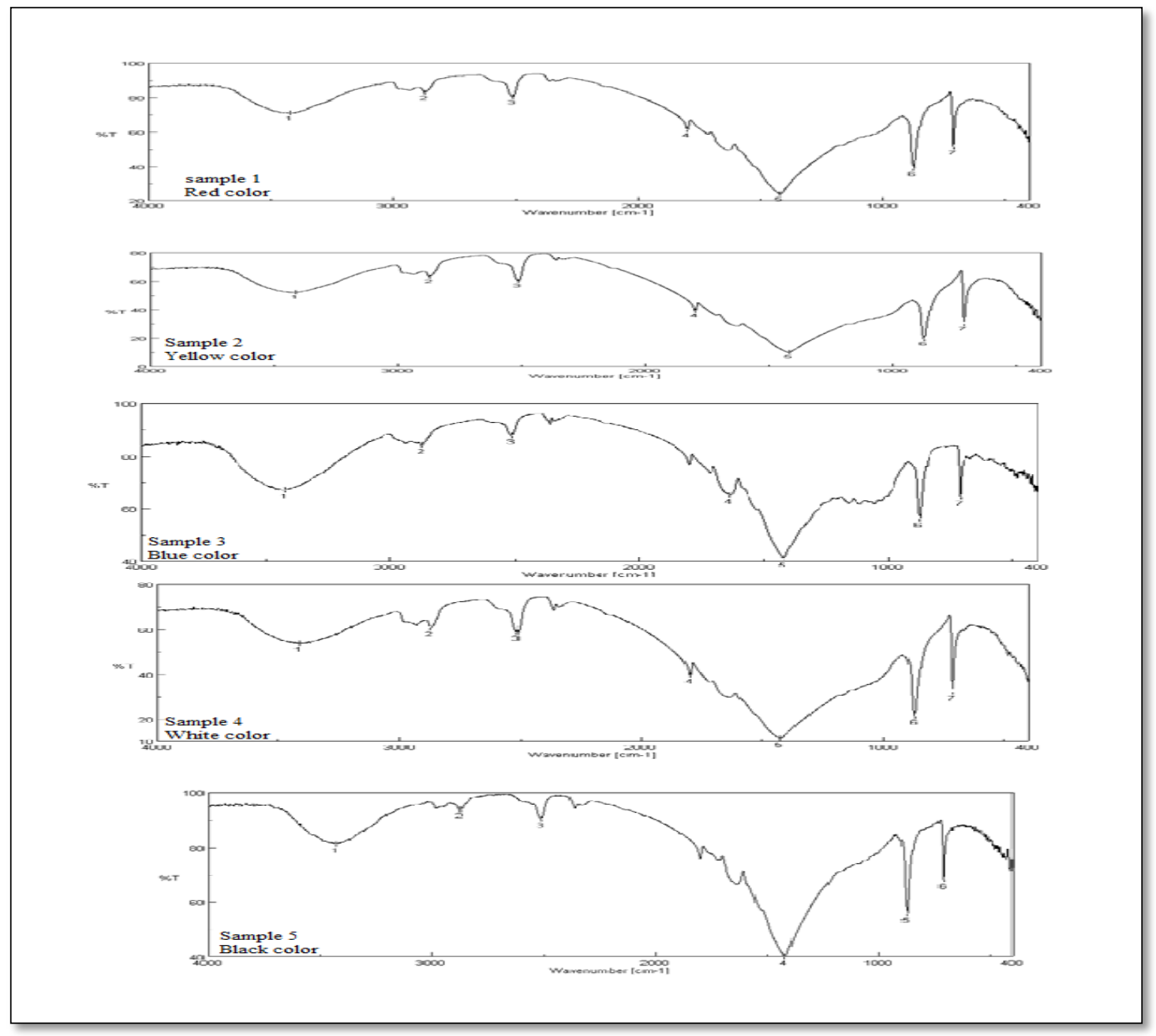

Fig. 25 FTIR pattern of samples from cartonnage

\section{4- Conservation process}

Cartonnage is subjected to a lot of damage as a result of poor storage of parts or as a result of the difference in temperature and humidity. It may expose the artifacts to various forms of damage from the occurrence of cracks and separation and micro-cracks and tears of the linen tissue. And this may T lead to a loss of the preparation layer and the color layer, and it would make it fragment and it collapse, so we start with the first treatment methods for cartonnage methods by cleaning operations using mechanical cleaning to remove dirt on the cartonnage surfaces as well as dirt stuck to the fabric layers by using appropriate tools such as soft brushes and also the use of a manual air blower, and then chemical cleaning is used to moisten the calcified dirt on the surfaces of the color layers by cutting cartonnage, which did not work with mechanical cleaning, using a solution of ethyl alcohol and distilled water in a ratio of 2: 1 and it is applied to the calcified dirt using a brush to moisten the calcified soil and then remove it using cotton and soft brush.

Also, a piece of cotton wrapped on a wooden stick (sticka) was used and the application is done in a circular motion with the change of the cotton pieces when dirty continuously, and then the place of application is dried using pieces of cotton, and ethyl alcohol and distilled water in a ratio of 1:1 are used to remove the remnants of dust. (Ali, M. F, 2016) and the use of ethyl alcohol and acetone in a 1: 1 ratio in removing linen residues, then after that a strengthening of the color layer is made by using Japanese tissue paper as a support and it is glued with klucel $\mathrm{G}$ with $3 \%$ concentration dissolved in ethyl alcohol and applied with a brush (Heba Sayed Galal, 
2014 ), and also the weak parts separated in the cartonnage layers were treated by injecting the separated part with Paraloid B 72 with 3\% concentration and it was placed inside between the layers and the glued material by injection (Mahmoud, G. A, 2020).

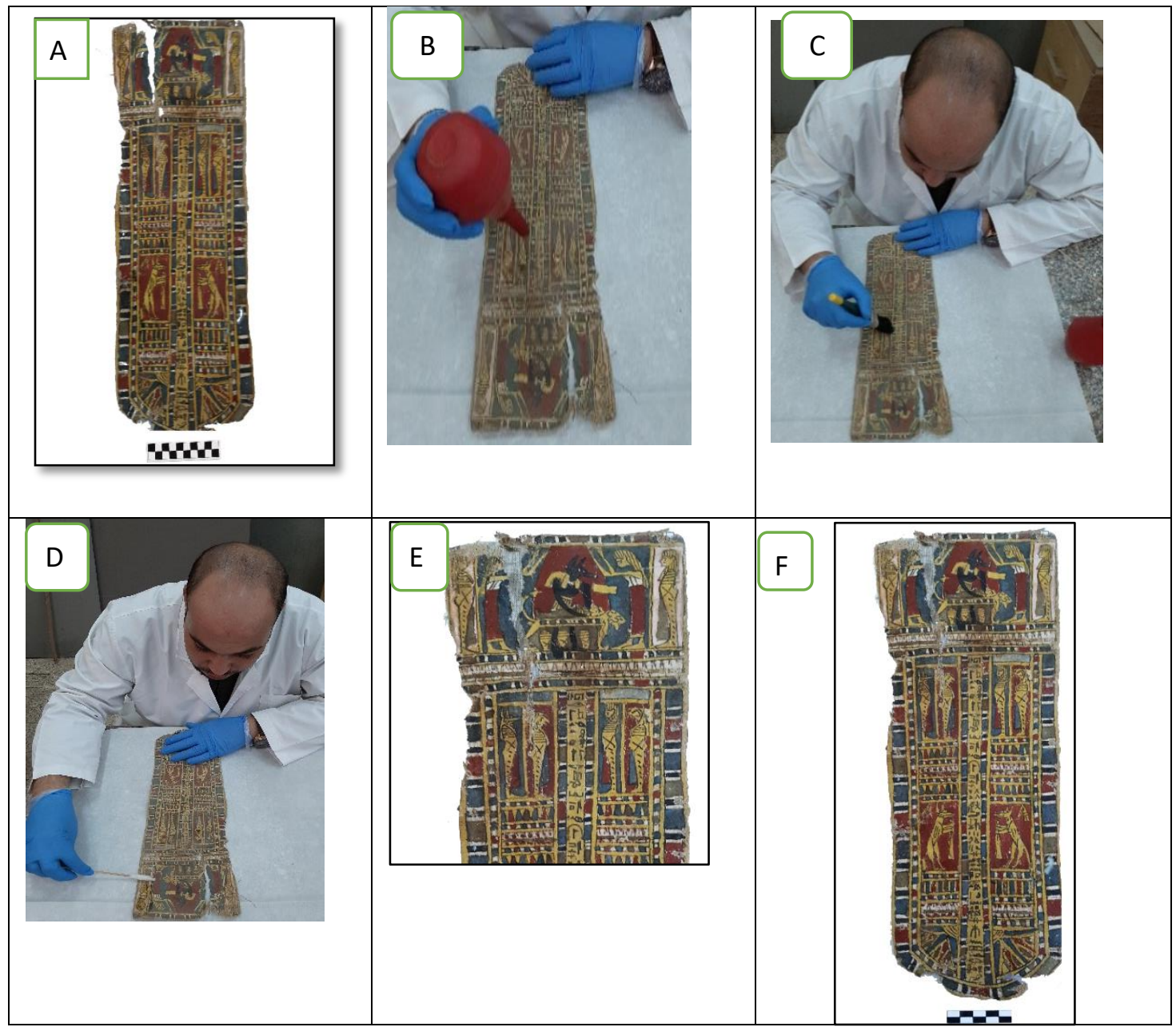

fig. (26) (A) shows the shape of the apron from the cartonnage before the restoration (B), (C) shows the mechanical cleaning using the blower and brushes to remove dust and dirt, (D) shows the chemical cleaning using the sticka (E) shows the work of consolidation the paint layer using klucel $\mathrm{G}$ at a concentration of $3 \%$ (F) shows the shape of the apron after Completion of restoration and conservation work

\section{5- Conclusion}

The FTIR analysis revealed that animal glue was the bonding material that used to prepare the preparation layer that consisting of $\mathrm{CaCO}_{3}$ for the cartonnage under the study on a plain linen fabric $1 / 1$.

And when using the X-ray diffraction analyzer XRD as well as X-ray fluorescence in the EDX material element analyzer located at the Egyptian General Authority for Mineral Resources, the colorant compounds were identified in the cartonnage piece, which dates back to the Roman era, as it was proven that the ancient Egyptian used the compound iron oxide $\mathrm{Fe}_{2} \mathrm{O}_{3}$ (hematite) as a source For the red color, and found that he used calcium silicate and copper $\mathrm{CaCuSi}_{4} \mathrm{O}_{10}$ (Egyptian blue) as a source for the blue color, and also used arsenic sulfide $\mathrm{AS}_{2} \mathrm{~S}_{3}$ as a source for the yellow color, and carbon $\mathrm{C}$ as a source for the black color, and the compound (calcite) $\mathrm{CaCO}_{3}$ was calcium carbonate as a source for the white color. 


\section{Reference}

$$
\begin{aligned}
& \text { 1- أماني محح كامل إبراهيم أبو كروره 2013 " فحص وتحليل مكونات بعض قطع الكارتوناج المصرية القديمة"، عصر }
\end{aligned}
$$

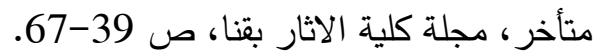

$$
\begin{aligned}
& \text { 2- هبة سيد جلال ،2014 " دراسة تطبيقية للتأثيرات المتبادلة والمتلفة بين طبقات الكارتوناج المذهب وطرق العلاج } \\
& \text { والصيانة "، رسالة ماجستير، قسم الترميم، كلية الاثار ، جامعة القاهرة، ص376. } \\
& \text { 3- فرانسوا دونان\& روجيه ليشينرج ،1997 " المومياوات المصرية من الموت الى الخلود "، ترجمه ماهر جويحانى، }
\end{aligned}
$$

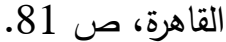

1- Ali, M. F., El Sheikha, A. M., \& Ali, A. E. (2016). Analytical Study and Conservation of Gilded Mummification Cartonnage from the Greco-Roman Period in Cairo Museum. Mediterranean Archaeology and Archaeometry, 16(2), pp.127-137.

2- David A. Scott, M., Narayan, K, Keeney, D \& Dodd.L;(2003)" An Egyptian car tonnage of the Graeo Roman period examination" \&dis covers, studies conservation, vol 47, pp.41-56.

3- David, A, Lynn Swartz Dodd, (2004) "Ancient Egyptian cartonnage Broad collar ", studies in conservation, vol.49.

4- David, S., Megan \&Dennis, (2003) "An Egyptian car tonnage of the Graeco - Roman period", study in conservation, vol.,48, N.1, p.24.

5- Dodson A, Ikram, S. (1998) "The Mummy in Ancient Egypt ", American university, pp.167 - 169 .

6- Gansicke, S., (2010). The conservation of decorated organic Egyptian surfaces: A literature review, in: Dawson, J., Rozeik, C. \& Wright, M. (eds.). Decorated surfaces on ancient Egyptian objects: Technology, deterioration and conservation, Archetype Pub., London, pp.67-77.

7- M.R. Derrick, D. Stulik, J.M. Landry (1999), Infrared Spectroscopy in Conservation Science, The Getty Conservation Institute, Los Angeles, pp. 97-98.

8- Mahmoud, G. A. (2020) "Gilding Technique and Conservation of a Gilded GrecoRoman Cartonnage in Hurghada Museum", Architecture, Arts and Human Sciences Journal - Five Volume - Twenty-fourth Issue, pp.1-14.

9- Putnam, J. (2009) "Eyewitness Mummy", British Museum, p.12.

10- Silver man D.P; (1997) "Ancient Egypt", New York Oxford, p.220.

11- Walker S. (1997)" Mummy portrait \& Roman portraiture ancient faces mummy portraits from roman Egypt ", British Museum, p.14.

12- Walker S; Bier brier M. (2000) " Ancient faces Mummy portrait from Roman Egypt ", London, p.163. 